\title{
Shielding the state of emergency: organised crime in Ireland and the state's response
}

\author{
Alan Greene \\ School of Law, University College Dublin ${ }^{1}$
}

Tn July 2009, after consulting the Council of State, President Mary McAleese signed the Criminal Justice (Amendment) Act 2009 (CJAA 2009) into Irish law without referring it to the Supreme Court under Article 26 of the Irish Constitution for an anticipatory test of its constitutionality. ${ }^{2}$ As much maligned as it was welcomed, the CJAA 2009 introduced wide-ranging powers to deal with organised crime including prolonged periods of detention, ${ }^{3}$ trials in front of the non-jury Special Criminal Court ${ }^{4}$ and the creation of the offence of membership of a criminal gang. ${ }^{5}$

At a time when concern about organised crime had reached unprecedented levels in the public and media domains in Ireland, ${ }^{6}$ such measures were considered by many as necessary to tackle effectively the actions of persons and organisations engaged in serious criminal activity. Others considered the CJAA 2009 to be of such a draconian nature that Ireland was being transformed into a police state and shamed in the eyes of the international community. ${ }^{7}$ The purpose of this paper is not to analyse or prophesise on the effectiveness of the CJAA 2009 in tackling the problem of organised crime; rather what will be explored is the political and legal correlation between the Act and the means by which states react to emergencies.

1 PhD Candidate and holder of the UCD School of Law Doctoral Scholarship: alan.greene1@ucdconnect.com. I would like to thank Professor Sally Wheeler and the editorial board of the Northern Ireland Legal Quarterly for their comments on earlier drafts of this paper and Dr Fiona de Londras, UCD School of Law for her invaluable contribution.

2 Under Article 26 of the Irish Constitution, the President may refer a Bill to the Supreme Court to test its constitutionality before it is signed into law. See R Byrne and J P McCutcheon, The Irish Legal System 4th edn (Dublin: LexisNexis Butterworths 2002), para. 5.71-5.

3 S. 16 amends s. 41 of the Criminal Justice Act 1999 increasing the penalty for jury and witness intimidation from 10 years to 15 years. The offence of directing a criminal organisation under s. 5 may be punishable by life imprisonment and the offence of participating in or contributing to certain activities under s. 6 may be punishable by up to 15 years' imprisonment.

4 S. $8(1)$.

5 S. 5 amends s. 71 of the Criminal Justice Act 2006 to create the offence of "directing a criminal organisation". S. 6 amends s. 72 of the Criminal Justice Act 2006 and makes it an offence to "participate in or contribute to certain activities" which are subsequently outlined.

6 See L Campbell, "Responding to gun crime in Ireland" (2010) 50 British Journal of Criminology 414, p. 417.

7 "Criminal Justice (Amendment) Bill”, Irish Times, Dublin, 8 July 2009. 
As declaring a state of emergency in general permits derogations on human rights obligations and encroachments on the separation of powers doctrine, scrutiny of the existence of such an emergency should be of paramount importance for legislators and the judiciary alike. ${ }^{8}$ Consequently, a "state of emergency" may be described as a "sword and a shield" from a human rights and democratic perspective. As a sword it allows a state to breach human rights obligations that ordinarily constrain the range of responses a state may undertake. Yet also, in an ideal type situation, by outlining the discrete conditions when such measures may be undertaken, a state of emergency may also act as a shield, constraining such draconian measures and protecting human rights and democracy in times when conditions do not meet the sufficient severity threshold in order to constitute a state of emergency.

However, an emergent trend in the literature and empirical evidence is that it is now impossible to isolate and separate a state of emergency from normalcy. This is related to three different issues. Firstly, conditions that would not previously have been described "emergencies" are being increasingly used to justify the declaration of a state of emergency. The term emergency, already elastic in nature, is therefore becoming stretched to a point whereby it snaps and becomes useless in describing what conditions should trigger an emergency. Secondly, the phenomena in modernity that trigger a state of emergency are often incapable of temporal or spatial separation from the background of normalcy resulting in an "entrenched" or "perpetual" emergency. Finally, states often respond to situations in a manner similar to the way they would respond during a state of emergency without actually declaring a state of emergency to exist; in other words, de facto emergencies are emerging. In such situations, normalcy is technically in existence in strict legal terms (i.e. there is no de jure state of emergency) but the state is engaging in activities more akin to emergency situations (i.e. there is a de facto state of emergency). The result of this tri-frontal attack on the emergency paradigm is that the "shielding effect" of emergencies is being eroded, while their hazardous effects on human rights, democracy and the rule of law not only remain but are expanded. By showing a correlation between the CJAA 2009 and an emergency response in the absence of a legally declared state of emergency, this paper argues that the Irish government's response to organised crime seriously threatens the shielding effect of emergencies and lends weight to arguments that the emergency paradigm is obsolete.

This paper commences with an outline of what constitutes an emergency and an emergency response. Part 2 illustrates the correlation between the previously constructed paradigm and the CJAA 2009. Finally, this paper concludes with a discussion of the consequences of utilising an emergency response in dealing with organised crime and the implications this may have on formulating an understanding of the nature of emergencies and dealing with threats to the life of the nation.

\section{Discerning the emergency paradigm}

The idea of a state of emergency cannot truly be defined in any concrete, juridical manner. In fact, attempts to do so may be counter-productive, resulting in an inflexible concept

8 It is beyond the scope of this paper to enter into discussion on which body is most effective in evaluating the existence of an emergency. Indeed, such a discussion would warrant a separate article in itself. For our purposes it is enough to assume that a declaration of emergency is in general left to the realm of the politicians and the executive as the slow judicial process could hamper an effective response. Similarly, a court or judicial procedure as to the existence of an emergency would require the disclosure of matters of state security which often require a high level of secrecy due to their sensitivity. See, generally, F de Londras and F Davis, "Controlling the executive in times of terrorism: competing perspectives on effective oversight mechanisms" (2010) 30(1) Oxford Journal of Legal Studies 19. 
devoid of practicality in situations where flexibility, discretion and speed are necessary. ${ }^{9}$ Reflecting this, legislative and constitutional sources of emergency powers do not generally offer strict definitions of a state of emergency, but use broad brushstrokes and give indications of situations in which a state of emergency may be deemed to exist in order to draw the parameters of these powers. Legally "defined" emergencies are therefore intangible in nature and elastic in applicability covering a multitude of phenomena. ${ }^{10}$ The term emergency itself connotes a destructive or dangerous event of great magnitude that requires a swift response, a level of urgency and a severe detriment incurred by the state if such a response is not taken. ${ }^{11}$ These situations constitute an emergency because of both the phenomenon that is the source of the crisis and the dire consequences that may result from an unresponsive state.

The purpose of declaring a state of emergency in legal terms is to permit a course of action that would otherwise be unavailable or even unlawful for the state to pursue. ${ }^{12} \mathrm{~A}$ state will always face crises of varying severity, yet not all these crises will qualify as emergencies. It is only when the crisis crosses a certain threshold of magnitude and urgency that a state of emergency may be declared. ${ }^{13}$ However, given the often increased scrutiny of a state's actions by international human rights bodies, observers and civil society once an emergency is declared, for reasons of mala fides a state may not actually declare a state of emergency even though it is reacting as if an emergency exists. ${ }^{14}$ Similarly, given the security biases that may influence a state in times of crisis, it may be prone to overestimating the severity of the situation and declare a state of emergency in conditions that may not warrant such a declaration in the eyes of an external observer. ${ }^{15}$ Consequently, it is necessary for the legal scientist to strive for an objective approach when assessing the existence of a state of emergency. Given the interdependent nature of the phenomenon and response which a state of emergency entails, I submit that we ought to observe a state's response in order to assess whether an emergency is thought to exist regardless of whether there has been a legal declaration to that end or not. This approach strives for a level of objectivity when

9 O Gross, "Once more unto the breach": the systematic failure of applying the European Convention on Human Rights to entrenched emergencies” (1998) 23 Yale International Law Journal 437, p. 438.

10 Ibid. p. 439.

11 This is surmised famously by Thomas Jefferson who said: "A strict observance of the written laws is doubtless one of the high duties of a good citizen, but it is not the highest. The laws of necessity, of self-preservation, of saving our country when in danger, are of higher obligation. To lose our country by a scrupulous adherence to written law, would be to lose the law itself, with life, liberty, property and all those who are enjoying them with us; thus absurdly sacrificing the end to the means." See J Lobel, "Emergency power and the decline of liberalism" (1989) 98 Yale Law Journal 1387, p. 1393.

12 Hence, in international human rights law sources of emergency powers are often called "derogation clauses" as they permit a state to derogate from some of its ordinary obligations under the treaties. In addition, Article 28.3.3 of the Irish Constitution explicitly states that: " $[\mathrm{N}]$ othing in this Constitution other than Article 15.5.2 shall be invoked to invalidate any law enacted by the Oireachtas which is expressed to be for the purpose of securing the public safety and the preservation of the State in time of war or armed rebellion, or to nullify any act done or purporting to be done in time of war or armed rebellion in pursuance of any such law." Article 15.5.2 refers to the prohibition of the death penalty.

13 Of course the identification of this "threat-severity threshold" may not be capable of scientific analysis. There will invariably be debate as to whether or not a threat does cross this severity threshold. A "state of emergency", as we shall see, is very much a legal term whereby there will be cases which come within the core understanding of the term, and those which are very much within the "penumbra" of "emergency". See H Hart, "Positivism and the separation of law and morals" (1958) 71 Harvard Law Review 593, p. 607.

$14 \mathrm{~J}$ Fitzpatrick, Human Rights in Crisis: The international system for protecting rights during states of emergency (Philadelphia: Philadelphia UP 1994), p. 18.

15 O Gross, "Chaos and rules: should responses to violent crises always be constitutional?" (2000) 112 Yale Law Journal 1011, pp. 1038-41. 
ascertaining the existence of a state of emergency and allows one to critically analyse situations when a state does declare an emergency and to infer the existence of an emergency even if not officially declared or recognised by a state party. In other words, it offers a mechanism of recognising de facto and not only de jure emergencies. ${ }^{16}$ Inquiry as to the existence of an emergency should therefore move beyond the legal realm to analyse the socio-political context within which the legal response takes place. Within this wider sphere of analysis, we can focus on discerning the following key constituent parts of an emergency response: reaction to a "serious" threat, representation of that reaction as necessary, and the separation of emergency from normalcy and assertion of abnormality.

\section{REACTION tO A "SERIOUS" THREAT}

In order for an emergency to exist, a real and imminent threat to the state must exist that warrants a situation being described as such. Emergencies are consequently reactive in nature ${ }^{17}$ and ideally cannot be pre-emptively declared in order to deal with a hypothetical threat. ${ }^{18}$ In addition, the nature of this threat may be completely different from one emergency to another. Given the difficulties arising from the intangible nature of emergencies, attempting to identify and describe which scenarios cross the requisite threatseverity threshold thus warranting an emergency response can itself be challenging. That conceded, it is possible to identify core cases in which the existence of an emergency would be undisputed. The dictatorship of the Roman Republic is a prime lens through which we can view these core cases of undisputed states of emergency.

The dictatorship of the Roman Republic is seen as the archetypal emergency response mechanism and, consequently, as an ideal type through which one can analyse the concept of emergency and what threats may warrant an emergency response. In times of crisis, when the ordinary system of governance was unable to act decisively, power would be consolidated in a single individual: the dictator. ${ }^{19} \mathrm{He}$ was appointed for a period of six months to deal with the threat and was empowered to do anything he considered to be necessary to further his cause. ${ }^{20} \mathrm{He}$ could not be held to account for his actions once he relinquished office, however, he could neither extend his period of office nor appoint another dictator. He was also unable to make laws so the legal system that existed before he was appointed remained exactly the same once he abdicated from his office. ${ }^{21}$ The military nature of the Roman dictatorship was written into its DNA; his original title of magister populi translates as master of the citizen army, ${ }^{22}$ the duration of his term in office - six months equated to the working year of the army in the ancient world, ${ }^{23}$ and the dictatorship was most frequently used in the early days of the republic when the state had not a firm enough basis to maintain itself against foreign invasion. ${ }^{24}$ However, the dictatorship was also used to deal with natural disasters such as the outbreak of plague. ${ }^{25}$ The inherent power (imperium)

16 Gross, “Chaos and rules”, n. 15 above, p. 310. See also Fitzpatrick, Human Rights, n. 14 above, pp. 21-2.

17 O Gross and F Ní Aoláin, Law in Times of Crisis: Emergency powers in theory and practice (Cambridge: CUP 2006), p. 22.

18 "The Siracusa Principles on the Limitation and Derogation Provisions in the International Covenant on Civil and Political Rights" (1985) 7 Human Rights Quarterly 3, p. 8.

19 C Rossiter, Constitutional Dictatorship (London: Transaction Publishers 2002), ch. 1.

20 A dictator was appointed re gerundae causa (to get things done). Ibid. p. 21. Rossiter also describes the dictator as "as absolute a ruler as could well be imagined", p. 23.

21 N Machiavelli, The Discourses (London: Routledge \& Kegan Paul 1950), p. 194.

22 Gross and Ní Aoláin, Law in Times of Crisis, n. 17 above, p. 21.

23 Rossiter, Constitutional Dictatorship, n. 19 above, p. 26.

24 J-J Rousseau, The Social Contract and Discourses (London: Everyman 1993), p. 294.

25 D Cohen, “The origin of Roman dictatorship" (1957) 10 Mnemosyne 300, p. 305. 
of the dictator gave him an almost spiritual potency, enabling him, for example, to tackle disease by hammering a nail into a tree that was considered to be the source of the plague. ${ }^{26}$ Extrapolating from this archetypical example of emergency powers, it would appear that war or severe natural disaster constitute core cases of emergency.

Modern sources of emergency powers corroborate the assertion that war or armed insurrection would warrant a state of emergency: Article 28.3.3 of the Irish Constitution, which lays down broad emergency powers, explicitly mentions a "time of war or armed rebellion". ${ }^{27}$ In international human rights law, the Siracusa Principles interpret Article 4 of the International Covenant on Civil and Political Rights (ICCPR) ${ }^{28}$ which deals with declarations of emergencies as requiring "a situation of exceptional and actual or imminent danger which threatens the life of the nation";29 similarly Article 15 of the European Convention on Human Rights (ECHR) ${ }^{30}$ describes a time of "war or emergency threatening the life of the nation".

The phrase "threatening the life of the nation" is arguably the clearest indication in Article 15 of what an objective analysis of what constitutes an emergency entails. That notwithstanding, however, a consideration of the caselaw on this issue is of little assistance in discerning the severity threshold a threat must reach in order to warrant a declaration of a state of emergency. In Lawless $\mathrm{v}$ Ireland, ${ }^{31}$ an emergency was defined as:

a situation of exceptional and imminent danger or crisis affecting the general public as distinct from particular groups and constituting a threat to the organised life of the community which composes the state in question. ${ }^{32}$

The minority in this case sought a more rigorous definition of emergency, tantamount to war, that could only be said to exist when the constitutional order had broken down. ${ }^{33}$ Nevertheless, a lay reading of the preferred interpretation would suggest a threat would have to meet quite a strict threshold of severity in order to justify a state derogating its obligations under Article 15 of the ECHR. There is, however, a dramatic divergence between the theory and the facts which the court considered amounted to an emergency in the Lawless case and in subsequent jurisprudence.

In Lawless, the threat posed to the Republic of Ireland by the Irish Republican Army (IRA) was deemed to constitute an emergency as:

in the first place, the existence in the territory of the Republic of Ireland of a secret army engaged in unconstitutional activities and using violence to attain its purposes, secondly, the fact that this army was also operating outside the territory of the state, thus seriously jeopardising the relations of the Republic of Ireland with its neighbour; thirdly, the steady and alarming increase in terrorist activities from the autumn of 1956 and throughout the first half of $1957 .{ }^{34}$

This is in spite of the fact that the IRA posed no threat to the institutions of Ireland, never mind to the existence of the state itself. Indeed, Gross and Ní Aoláin note with scorn

26 Cohen, "The origin", n. 25 above.

27 Article 28.3.3 further states that: "time of war includes a time when there is taking place an armed conflict in which the State is not a participant but in respect of which each of the Houses of the Oireachtas shall have resolved that, arising out of such armed conflict, a national emergency exists".

28 Adopted 16 December 1966, entered into force 23 March 1976, 999 UNTS 171 ICCPR.

29 “The Siracusa Principles", n. 18 above, p. 3.

30 Convention for the Protection of Human Rights and Fundamental Freedoms (ECHR, as amended).

313 ECHR (Ser A) (1960-61).

32 Lawless $\mathrm{v}$ Ireland 1 ECHR (Ser B) (1960-61) (Commission Report), para. 90.

33 Gross and Ní Aoláin, Law in Times of Crisis, n. 17 above, p. 249.

34 Lawless v Ireland 1 ECHR (Ser B) (1960-61) (Commission Report), para. 28. 
the idea that an indirect deterioration of international relations between two governments could be used to infer the existence of an emergency. ${ }^{35}$ Such a finding of fact stands vastly out of line with a literal interpretation of the phrase "threatening the life of the nation".

Thus, the severity threshold which a crisis must meet to correspond to an emergency under the ECHR is much lower than one would expect. In spite of this problem, however, there are some key identifiable indicators such as the fact that the political nature of the threat is considered to be a central element of phenomena that legitimise an emergency response. Protecting the life of the nation entails protecting not just the citizens of the state but also the institutions of governance and the legal order. Lawlessness and anarchy that may ensue in the aftermath of a natural disaster would also produce the requisite political nature of a threat to warrant a declaration of emergency. Similarly, the symbolic nature of terrorist attacks as an affront to the legitimacy of a state's claim to sovereignty would qualify as a threat to the life of the nation given their (generally) political nature. ${ }^{36}$

\section{THE REPRESENTATION OF NECESSITY}

The Roman dictator was appointed in order to allow the state to act in a manner that was otherwise prohibited under the legal and political conditions of normalcy. In modernity, declaring an emergency in some jurisdictions allows for the introduction of measures that would otherwise be not only unlawful but in fact unconstitutional. Article 28.3.3 of the Irish Constitution for example allows the state to pursue measures that would, but for a declaration of emergency, be deemed inconsistent with the provisions contained in the Constitution. ${ }^{37}$ It is in the nature of emergency measures that they are generally draconian in nature, sacrificing individual liberties and normal constitutional procedure for a more security-conscious state of affairs. ${ }^{38}$ These measures are, however, represented as being necessary (and justified) in order to protect the life of the state. ${ }^{39}$

The term emergency connotes a crisis that is unforeseen, sudden and requires immediate action. ${ }^{40}$ The speed of a response is vital in order to combat the threat. The consolidation of powers in the dictator in Rome was designed to enable the dictator to act swiftly and decisively, free from the ordinary constitutional procedure of complex checks and balances that impeded swift decision-making in periods of normalcy. ${ }^{41}$ In modernity, emergencies generally result in the consolidation of powers in the executive branch of government at the expense of the legislature and judiciary. ${ }^{42}$ The executive is the body most capable of acting quickly and decisively given the general consensus of opinion at cabinet

$35 \mathrm{O}$ Gross and F Ní Aoláin, "From discretion to scrutiny: revisiting the application of the margin of appreciation doctrine in the context of Article 15 of the European Convention on Human Rights" (2001) 23 Human Rights Quarterly 625.

36 J Friedrichs, "Defining the international public enemy: the political struggle behind the legal debate on international terrorism" (2006) 19 Leiden Journal of International Law 69, p. 71.

37 Casey notes that Article 28.3.3 is extremely broad, effectively giving the Oireachtas carte blanche to legislate at will. Thus, theoretically, the Oireachtas could re-write the constitution, e.g. expanding the size of the Dáil and its duration, altering the balance of powers between the Oireachtas and government or decreasing the powers of the President. Indeed, the only caveat contained in Article 28.3.3 is a prohibition on the introduction of the death penalty. See J P Casey, Constitutional Law in Ireland 3rd edn (Dublin: Roundhall Sweet \& Maxwell 2000), pp. 180-1.

38 Lobel, "Emergency power", n. 11 above, pp. 1387-92.

39 Ibid. p. 1387.

40 Gross and Ní Aoláin, Law in Times of Crisis, n. 17 above, p. 171.

41 H F Jolowicz, Historical Introduction to the Study of Roman Law (Cambridge: CUP 1965), p. 153.

42 M Tushnet, "Controlling executive power in the war on terrorism" (2005) 118 Harvard Law Review 2673, p. 2674. 
or the absence of formal procedures that may slow down such decision making. In contrast, a slow legislative procedure is seen as dangerous, hampering the swift and decisive response that is necessary to dispose of the threat. ${ }^{43}$ Similarly, as the executive is afforded a level of secrecy, it is considered to be the body best situated to deal with matters of state security. ${ }^{44}$

\section{THE SEPARATION OF NORMALCY FROM EMERGENCY AND THE ASSERTION OF ABNORMALITY}

Emergencies and normalcy are composed in terms of a dichotomised dialectic. ${ }^{45}$ They are mutually exclusive with only one state in existence at any one time. Normalcy is considered to be the empirical regularity of modernity. It is the representation of the status quo and of the state as it exists from day to day. Emergencies on the other hand are conveyed as outliers to the status quo. They constitute rare phenomena that consequently require measures to tackle them that are equally rare. These often draconian measures are made more palatable and acceptable by their ultimate goal which is the restoration of normalcy. ${ }^{46}$ An emergency is only declared in order to utilise these extraordinary measures that in turn restore normalcy and the status quo. ${ }^{47}$ Without this goal, such draconian measures merely alter normalcy rather than protect it. In order to facilitate this distinction between normalcy and emergency, a number of mechanisms may be utilised. Restoration of normalcy indicates that emergencies are only temporary, as indicated by the common practice of placing (at least prima facie) temporal limits on emergencies. ${ }^{48}$ As we have already seen, for example, the Roman dictator was limited to six months in office without the opportunity of renewal. ${ }^{49}$ Often, however, he would step down before the six months was up once the threat was eliminated. ${ }^{50}$ As the threat ceased to exist, there was no need for his office. This temporal limit ensured and reassured Rome that the resort to authoritarianism was only temporary. ${ }^{51}$

Many modern manifestations of emergency powers also include express time limits to curtail a state of emergency. Constitutions such as those of Poland and Chile contain a time-limit expressed therein. ${ }^{52}$ Time limits may also be seen in emergency legislation such as the USA Patriot Act (passed in the aftermath of the 11 September 2001 attacks) and the UK Counter Terrorism Act 2005. ${ }^{53}$ In addition, the lack of an express time limit does not necessarily mean that a state of emergency may be permanent. Article 27 of the American Convention on Human Rights (ACHR) does not contain a time limit, however, the InterAmerican Court has ruled that such derogations on the basis of emergencies are only permitted "for the period of time strictly required by the exigencies of the situation". 54

43 E A Posner and A Vermeule, Terror in the Balance: Security, liberty and the courts (Oxford: OUP 2007), p. 45. See also G Lawson, "Ordinary powers in extraordinary times: common sense in times of crisis" (2007) 87 Boston University Law Review 289, p. 311.

44 de Londras and Davis, "Controlling the executive", n. 8 above, p. 27.

45 Gross and Ní Aoláin, Law in Times of Crisis, n. 17 above, p. 172.

46 ICCPR, General Comment No 29: States of Emergency (Article 4) 31 August 2001 c/21/Rev1/Add11.

47 The ICCPR's General Comment on Article 4 states that the purpose and justification of a derogation under Article 4 of the convention is the restoration of a state of normalcy where full respect for the covenant can again be secured. See ibid.

48 Gross and Ní Aoláin, Law in Times of Crisis, n. 17 above, pp. 174-81.

49 Rossiter, Constitutional Dictatorship, n. 19, p. 23.

50 Ibid. p. 24.

51 Machiavelli, Discourses, n. 21, p. 194.

52 Article 40.1 of the Chilean Constitution requires a state of siege, state of emergency or internal commotion to last no longer than 90 days but it may be renewed by the President subject to legislative oversight. Similarly Art. 230 of the Polish Constitution states that a state of emergency lasts for a period of 90 days but may be subject to a renewal for a period no longer than 60 days.

53 See, however, Part 3 below (p. 260), in this article and how these time limits have operated in practice.

54 See further, however, on how the ECHR has interpreted Article 15 in $A$ v UK. 
As emergency powers are equipped to deal with a threat, one may reasonably expect that they will only be utilised against the threat. A distinction is thus made during states of emergency between friend and enemy. ${ }^{55}$ Ideally, the draconian measures only impact negatively on those who are considered enemies of the state. Theoretically, they should not impact on the ordinary person in society, however, if they do, once the enemy is neutralised, the need for such draconian measures is assuaged, the measures cease to exist and normalcy is restored. As the enemy has been neutralised, he too no longer exists in normalcy.

A third distinction may also be made in terms of a geographical or spatial context. ${ }^{56}$ Different rules may be applied in different areas. Emergency powers will only be utilised in areas where a threat is evident, e.g. a war zone, the aftermath of a natural disaster, etc. The dictator generally utilised his powers in leading the army outside the walls of Rome, however, given the close proximity between ordinary life and the military sphere, the appointment of a dictator essentially turned all of Rome into a war camp. ${ }^{57}$ In modernity, the US Federal Emergency Management Agency (FEMA) uses this spatial separation between crisisaffected and non-crisis-affected areas in order to define the disaster and allocate resources accordingly. "Emergency" is used to describe a catastrophe with local effects managed with local resources. ${ }^{58}$ Proceedings along this continuum of magnitude and space, a catastrophe is considered by FEMA to have national implications with local resources ineffective. 59

We are thus left with the above parameters indicative of an emergency response and which may be used to stress-test government actions both when a state of emergency is formally declared (de jure state of emergency) and when one is not declared (possible de facto state of emergency). One is therefore able to objectively analyse the state's reaction to a phenomenon and describe it as an emergency response independent of the state's own assessment of the situation.

The next part of this article contains an analysis of the legal implications of the CJAA 2009 as well as the socio-political background surrounding the enactment of the legislation in light of these parameters with a view to assessing its correlation to the emergency response paradigm outlined here and the consequential impact this has on human rights, democracy and the rule of law in Ireland.

\section{Is the CJAA 2009 an emergency response?}

Organised crime has been of increasing concern in Ireland since the killing of journalist Veronica Guerin in $1996 .{ }^{60}$ Hard on the heels of the moral panic ${ }^{61}$ that ensued in the aftermath of her death, the government at the time introduced a series of measures, such as the Criminal Assets Bureau, to deal with this apparent new phenomenon. ${ }^{62}$ Echoing this situation, it was the killing of Roy Collins in Limerick that crystallised media and public

55 Gross and Ní Aoláin, Law in Times of Crisis, n. 17 above, p. 220.

56 Ibid. p. 181.

57 Rossiter, Constitutional Dictatorship, n. 19 above, p. 21.

58 See http://training.fema.gov/emiweb/edu/docs/crr/Catastrophe\%20Readiness $\% 20$ and $\% 20$ Response $\% 20$ $\% 20$ Session $\% 201 \% 20-\% 20$ Course $\% 20$ Intro.ppt.

59 Ibid.

60 I O'Donnell and E O’Sullivan, “The politics of intolerance Irish style” (2003) 43 British Journal of Criminology 41, p. 49.

61 See, generally, S Cohen, Folk Devils and Moral Panics: The creation of the mods and rockers (New York: St Martins Press 1980). See also Campbell, "Responding to gun crime", n. 6 above, p. 428.

62 Campbell, "Responding to gun crime", n. 6 above. See also I O’Donnell, "Crime and justice in the Republic of Ireland" (2005) 2(1) European Journal of Criminology 99, p. 101. 
outrage at organised crime in 2009 and prompted the Oireachtas to pass the CJAA 2009 in July of that year. ${ }^{63}$ This reaction bears all the hallmarks of an emergency response. An apparently serious threat to the state was identified by the government, Oireachtas and media, requiring a swift decisive response that had grave repercussions for human rights and the democratic order in Ireland.

\section{REACTION to a "SERIOUS" THREAT}

Crimes are by definition committed against the state. Yet, it would be spurious to consider all crimes to be a threat against the life of the nation as most criminal activity is not of a political nature. Terrorism in contrast, while often reduced by politicians to merely criminal acts, nevertheless is distinguished from ordinary acts of criminality due to its inherently political nature. ${ }^{64}$ It is submitted that the debate surrounding organised crime has portrayed its participants and the crimes they commit as equivalent to terrorist activity. ${ }^{65}$ Their actions are distinguished from ordinary criminal acts, obtaining a level of politicisation that qualifies them as a threat to the state, its citizens and the rule of law. Politicians and the media are the main source of this rhetoric, distinguishing organised crime from "ordinary" crime and attempting to create an equivalency between organised crime and terrorism. Organised crime is considered "an affront to society just as the terrorists who were running around this island were an affront to society". ${ }^{66}$ Consequently, "The men who prey on our society are treated as terrorists". 67

The strongest endorsement of organised crime as a threat to the state in the context of the passage of the CJAA 2009 was articulated by Labour TD Tommy Broughan calling such acts "A threat to the state ... such a threat to society ... [that] . . can't be allowed go on."68 Minister for Justice Dermot Ahern reiterated the notion on numerous separate occasions, saying that the "grave situation we face" had "brought communities to their knees" and constituted a threat to the nation:

Members of these gangs have displayed a callous disregard for human life and a brazen contempt for the community. They have come to believe that they can take on the criminal justice system and act as a law unto themselves. It is beyond

63 In media interviews and Dáil debates, Minister for Justice Dermot Ahern frequently invoked the circumstances surrounding the murder of innocent rugby player Roy Collins to justify the introduction of the CJAA 2009. See Dáil Debates, vol. 687, No 2, 3 July 2009. See also M Clifford, "New gangland laws would put us on par with tin-pot dictatorships; the Criminal Justice (Amendment) Bill is a PR stunt for Dermot Ahern, who knows the means to really hit gangs will be cut", Sunday Tribune, Dublin, 12 July 2009.

64 Although there is no universally accepted definition of terrorism, numerous sources of terrorist definitions specifically mention the political nature of such terroristic acts. See, generally, Gross and Ní Aoláin, Law in Times of Crisis, n. 17 above, pp. 366-71. Thus the 1999 International Convention for the Suppression of the Financing of Terrorism and Security Council Resolution 1566 (2004) describes terrorism as: "any action ... . that is intended to cause death or serious bodily harm . . . to compel a Government or an international organization to do or to abstain from doing any act". Similarly, the UN General Assembly's working definition of terrorism delineates the phenomenon as "criminal acts intended . . to provoke a state of terror in the general public ... for political purposes". See also T Miesels, The Trouble with Terror: Liberty, security and the response to terror (London: CUP 2008), pp. 5-30. Also, as Ashworth has shown, the increased politicisation of criminal acts is not a new phenomenon. See A Ashworth, "Crime, community and creeping consequentialism" (1996) Criminal Law Review 220.

65 "Editorial: Vital first step in defeating gangs", Sunday Independent, Dublin, 18 April 2009.

66 Ibid.

67 Ibid.

68 S Coleman, “Labour TD defends his 'gut feeling' in defying party on Criminal Justice Bill”, Sunday Tribune, Dublin, 12 July 2009. 
question that criminal gangs will try to take whatever action is open to them to thwart the criminal justice system. ${ }^{69}$

Organised crime was thus portrayed as a phenomenon that undermines the rule of law and legitimacy of the state, threatening the life of the nation and its citizens. Members of the opposition were keen to go along with this correlation between organised crime and terrorism with Opposition Leader Enda Kenny describing the situation "as a war which the Taoiseach does not appear to be winning". ${ }^{70}$ By hyperbolising the threat that organised crime poses to society, support and justification for draconian measures to counter the threat were achieved and consequently the measures were enacted.

\section{THE REPRESENTATION OF NECESSITY}

The portrayed seriousness of the threat by politicians and the media was used to justify enshrining "necessary" powers in legislation to tackle the serious problem of organised crime, hence the CJAA 2009. Amongst other provisions, the Act introduced the offence of directing a criminal organisation. ${ }^{71}$ In assisting the prosecution in proving this offence, a member of the Irish police force (An Garda Síochána), regardless of rank, who, it appears to the court, possesses the appropriate expertise, may express an opinion as to the existence of a particular organisation. Provision is also made for the potential of post-release supervision for a person convicted of such an offence, similar to that for registered sex offenders. ${ }^{72}$

Arguably the most draconian measure introduced by the Act is contained in s. 8. It states that the ordinary courts are inadequate to secure the effective administration of justice and the preservation of public peace. Consequently, the non-jury Special Criminal Court will be used to try certain organised crime-related offences. Originally established to deal with counter-terrorist cases and dissidents, ${ }^{73}$ the Special Criminal Court has been subject to a number of criticisms from human rights bodies, such as the United Nations Human Rights Commission, due to its impact on the right to a trial in due course of law. ${ }^{74}$ By utilising the Special Criminal Court, the Oireachtas enshrined the organised crime-terrorism equivalency in law. Organised crime was thus crystallised as a threat to the life of the nation, justifying such draconian encroachments on civil liberties and representing them as increasing the security of the ordinary law-abiding citizen.

The scope of measures introduced in the CJAA 2009 prompted a barrage of criticism from a number of sources. More than 130 lawyers wrote a letter to the Irish Times claiming Ireland would be shamed by the Act in the eyes of the world. ${ }^{75}$ Similarly, Labour Senator, professor of criminal law and practising barrister Ivana Bacik expressed staunch objection to placing organised crime cases before the Special Criminal Court, arguing that this would create a separate justice system running parallel to the ordinary courts and thus

69 Dáil Debates, vol. 687, No 2, 3 July 2009.

70 Dáil Debates, vol. 666, No 3, 11 November 2008.

71 S. 5 .

72 S. 14.

73 See F Davis, The History and Development of the Special Criminal Court 1922-2005 (Dublin: Four Courts Press 2007), pp. 64-70. Davis notes that the Offences against the State Act 1939 which first created the Special Criminal Court was drafted at a time when the activities and statements of the IRA were increasingly challenging the state's authority. Indeed, the general political unrest at the time explains why the Constitutional Review Group of 1934 suggested the inclusion of a clause permitting the establishment of non-jury courts in the new constitution. This became enshrined in Article 38.3 of the 1937 constitution. See ibid. pp. 56-62.

74 Human Rights Committee Concludes Sixty-Ninth Session, HR/CT/587, www.un.org/News/Press/docs/2000/ 20000728.hrct587.doc.html.

75 “Criminal Justice (Amendment) Bill”, Irish Times, Dublin, 8 July 2009. 
undermining the judicial system as a whole. ${ }^{76}$ The Irish Council for Civil Liberties (ICCL) described the measures as seeming to "fly in the face of our own Constitution and international norms. To have this situation in 2009 in a republic strikes me as extraordinary." Furthermore, the ICCL argued that the legislation "bears all the hallmarks of a police state". ${ }^{77}$

The severity of the measures contained in the CJAA 2009 was acknowledged by Minister Ahern who conceded that the state had "stretched the elastic as far as we can in any democracy" ${ }^{78}$ Yet that admitted, the measures were frequently defended as being necessary ${ }^{79}$ and consequently justified when dealing with the threat organised crime posed to the nation. The Garda Commissioner echoed similar sentiments calling the measures "proportionate and necessary". 80

Although the CJAA 2009 was comfortably passed by both houses of the Oireachtas, there was controversy at the speed at which it was enacted. The period of debate was drastically curtailed to a mere 90 minutes by the government's use of a guillotine procedure. ${ }^{81}$ Although Fine Gael supported the Bill, it frequently expressed concern at the way Minister Ahern appeared to be "rushing the legislation through". 82 Even members of government parties expressed concern with the speed at which it was passed, with Ciarán Cuffe TD remarking that he would prefer more time for the Bill to be debated but conceded it was not a point he would be pressing. ${ }^{83}$ Minister Ahern, however, defended the need to rush the legislation through as "from the minute it is passed people can be charged with directing criminal organisations and participating in criminal organisations . . . we cannot wait three months". ${ }^{84}$ Similar sentiments were echoed in the media with Kevin O'Connor remarking in the Irish Times that: "Limerick needs this now." 85 Under this representation, organised crime was portrayed as a phenomenon requiring urgent action which could not be postponed.

The manner in which the CJAA 2009 passed through the Oireachtas is indicative of a consolidation of powers in the executive in periods of emergency: the gravity and nature of the threat is one that we are told must be dealt with swiftly, the luxury of time to allow the cogs of democracy to grind in the usual way is not one which can be afforded, normal parliamentary procedure and constitutional "niceties" must be sacrificed for the sake of society and the nation. In other words, the legislature accedes to the "diktat from government", 86 acting as no more than a rubber stamp for the will of the executive.

\section{THE ASSERTION OF ABNORMALITY}

Although the use of the Special Criminal Court to deal with organised crime was acknowledged to be a serious power with the potential for severe encroachments on the right to a fair trial, Minister Ahern stressed a number of safeguards to mitigate the potential

76 I Bacik, "Senator Bacik speaking on Criminal Justice Legislation and Israel", www.ivanabacik.com/ archives $/ 309$.

77 "Court laws 'fly in the face of the Constitution", Irish Examiner, Cork, 4 July 2009.

78 “Gang lords facing life terms in crackdown”, Irish Independent, Dublin, 26 June 2009.

79 J Walsh, "Ahern stresses need for new powers", Irish Times, Dublin, 15 July 2009.

80 Ibid.

81 M Regan, "Dáil debate on gang laws cut to just 90 minutes", Irish Examiner, Cork, 3 July 2009.

82 "Government denies coalition rift over gangland crime Bill", Irish Independent, Dublin, 10 July 2009.

83 M Hennessy, “Greens want more time to debate Bill”, Irish Times, Dublin, 6 July 2009.

84 "Ahern denies introducing gangland Bill too quickly", Irish Independent, Dublin, 18 July 2009.

85 K O’Connor, "Using Constitution as a mask for self-interest”, Irish Times, Dublin, 9 July 2009.

86 Coleman, "Labour TD”, n. 68 above. 
scope of the measures in an attempt to afford a certain level of protection for the rights in question. Section 8(4) states that:

This section shall ... cease to be in operation on and from the date that is 12 months from the passing of this Act unless a resolution has been passed in each house of the Oireachtas resolving that this section should continue in operation.

Section 8 therefore appears temporary in its nature. If it is not renewed after 12 months it will cease to exist. The relevant crimes under s. 8 would no longer be able to go to the Special Criminal Court and would have to be dealt with in the ordinary courts. If such an outcome were to occur, then one would have to assume that the ordinary courts were once again capable of dealing adequately with organised crime. The time limit therefore extrapolates the current threat of organised crime from the background of normalcy and portrays it as a temporary phenomenon. Once the threat is defeated, s. 8 will simply expire as the need for it will no longer be evident. A balance is apparently struck between the need for swift decisive action to protect the security needs of the state and the human rights of its citizens as such encroachments are merely temporary, ${ }^{87}$ provided of course the time limit is actually given effect and not easily renewed.

As stated previously, political and media rhetoric surrounding the Act attempted to suggest an equivalence in severity between organised crime and terrorism. By describing murders and related crimes as "gangland", a separation between friend and enemy was made. The "us v them" model was utilised to distinguish the perpetrators from the rest of society. ${ }^{88}$ Consequently, the measures enacted in the 2009 Act will not affect society as a whole but merely those involved in gangland activity. The measures are therefore more palatable to society as a whole because the ordinary person's rights are not being encroached upon. ${ }^{89}$ A geographical distinction is also employed by the term gangland. Immediately, one thinks of areas in major cities such as Dublin and Limerick in relation to which there is frequent media reporting of organised crime. A geographical distinction is thus made between "normal" law-abiding areas and zones in which the rule of law has broken down, areas in which necessary measures will be employed in order to re-establish the state's authority therein. ${ }^{90}$

The CJAA 2009 is thus presented by politicians and the media as an extraordinary measure that was necessary to deal with the corresponding extraordinary threat that faced the Irish state in the form of organised crime. This assumption of abnormality is thus illustrated by the substantive measures contained within the Act, the means by which the government forced the Act through the Oireachtas, and the political and media rhetoric surrounding the Act. It is this abnormality that both necessitates the measures contained within the Act and, in an ideal type situation, mitigates our concern as to the erosion of civil liberties because, once this abnormality disappears, so too will the necessity for the measures and consequently the Act itself disappear. We shall now explore how this theory plays out in reality.

\section{The consequences of using an emergency response to deal with organised crime}

The parallels between the situation in Ireland in July 2009 and the emergency paradigm are startling even though an emergency was not officially declared in accordance with Article

87 Gross, "Chaos and rules", n. 15 above, p. 1073.

88 See Friedrichs, "Defining the international public enemy”, n. 36 above, pp. 69-70.

89 Gross, "Chaos and rules", n. 15 above, pp. 1075-7.

90 Ibid. 
28.3.3 of the constitution or, indeed, with Ireland's various international human rights law obligations including Article 15 of the ECHR. As stated previously, the belief that one can separate normalcy from emergency is being increasingly challenged in the literature for three reasons: expansion of the term emergency to cover a multitude of phenomena; the inability to isolate a threat in modernity from the background of normalcy; and the use of emergency responses that do not coincide with an official declaration of a state of emergency or the equivalent. Consequently, the shielding effect of a state of emergency is reduced while its potential harmful impact increases. With the passing of the CJAA 2009, Ireland finds itself in a situation where a de jure state of normalcy prevails but a de facto state of emergency exists. The detrimental effect this has on the distinction between normalcy and emergency and the consequent potential to undermine human rights, democracy and the rule of law require consideration.

\section{ChALLENGING THE EMERGENCY-NORMALCY DICHOTOMY}

The emergency response paradigm is founded upon the fundamental assumption that one can separate normalcy from emergency. ${ }^{91}$ It is upon this assumption that the often draconian measures introduced in emergencies appear more palatable. The belief that they are necessary, temporary and shall only be used against "the enemy" should in principle placate the very real concerns one may have about the effect an emergency response has on human rights, democracy and the rule of law. Ultimately, however, it is this most fundamental of assumptions that is being increasingly challenged by the literature and empirical evidence.

Gross considers that in modernity it is impossible to differentiate between normalcy and exception given the increasingly blurred demarcations between the two states. ${ }^{92}$ The erosion of the assumption of separation between time/space and friend/enemy corroborate the notion that emergencies are now the norm. ${ }^{93}$ In modernity, threats to states have evolved, from simple armed invasion by a foreign army; rather such threats come in the intangible form of terrorism, the perpetrators of which wear no identifiable uniform differentiating them as an armed force. These "terrorists" live among and look like us. ${ }^{94}$ They are not limited in their actions to one geographical area and neither are the effects or implications of their acts. In the aftermath of the 11 September 2001 attacks in the USA, the UN Security Council passed Resolution 1368 requiring all member states to pass laws dealing with terrorism; the impact of the attack on the USA transcended borders and plunged the world into a state of emergency.

The fragility of the separation between normalcy and emergency is even more pronounced when the emergency paradigm is applied to a phenomenon like organised crime; a more mundane phenomenon of greater empirical regularity. By effectively othering those that partake in organised crime and clearly identifying the geographical areas in which such gangs operate, politicians and the media isolated the phenomenon of organised crime from the other experiences of people's lives in Ireland in 2009. However, the perpetrators of organised crime, like terrorists, wear no identifiable uniform that clearly demarcates them from civilians. Similarly, although organised crime is portrayed by the media and politicians as affecting certain core areas, Limerick city and Dublin, for example, ${ }^{95}$ these borders are clearly less robust than international borders and the implications and consequences of

91 Gross, "Chaos and rules", n. 15 above, pp. 1071-2.

92 Ibid. pp. 1089-95.

93 Ibid.

94 Ibid. pp. 1082-9.

95 Campbell, "Responding to gun crime", n. 6 above, p. 427. 
such criminal actions may not truly be confined within these areas. As a result, it is hard to identify when, if ever, the threat of organised crime may be wholly neutralised.

Indeed, there are some indications from the European Court of Human Rights (ECtHR) that the emergency paradigm as applied within international human rights law may be doctrinally stretched to encompass entrenched or perpetual emergencies. In response to the attacks on the USA and Security Council Resolution 1368, the United Kingdom declared a state of emergency and lodged a notice of derogation from some treaty provisions in accordance with Article 15 of the ECHR and Article 4 of the ICCPR. The existence of a state of emergency was subsequently challenged in $A \mathrm{v} U K^{96}$ in which the ECtHR held that, in light of the new threat of Islamic terrorism, an emergency declared under Article 15 could be perpetual in nature. ${ }^{97}$ Decisions of this kind add more weight to the argument that in fact a clear distinction between normalcy and emergency cannot be identified.

In addition to the attempted spatial separation and identification of the enemy by politicians and the media, the inclusion of a "sunset clause" requiring annual renewal of the Special Criminal Court provisions is an attempt to temporally extract the threat of organised crime from the background of normalcy. Again, this theoretically assuages the Act's potential impact on human rights. In reality, however, the theory behind such legislative time limits rarely corresponds with their implementation in practice, as can be seen in the history of the Special Criminal Court itself. Part V of the Offences against the State Act 1939 permits the establishment of the non-jury Special Criminal Court when the ordinary courts are considered to be no longer adequate. Conditions rendering the ordinary courts inadequate were deemed to exist during the Second World War from 1939-46, in light of increasing IRA activity from 1961-62 and, finally, in relation to the "troubles" in Northern Ireland from 1976 to the present day. ${ }^{98}$ The supposedly temporary nature of the language contained in Part V has nevertheless created a non-jury court that is essentially a permanent institution of the Irish legal system. ${ }^{99}$

The ineffectiveness of time limits may also be seen by analysing the United Kingdom's Prevention of Terrorism Act 2005. Sections 1-9 of this Act, which include provisions relating to control orders, must be renewed by the legislature each year. Despite the severe encroachments on individual liberties that these measures may impose without the need of a criminal trial and requisite burden of proof, ${ }^{100}$ their cost ${ }^{101}$ and apparent ineffectiveness in tackling terroristic activity, ${ }^{102}$ they have nevertheless been renewed annually; most recently in March 2010. ${ }^{103}$ In the USA in 2001, the Patriot Act made serious encroachments on citizen's individual rights, such as those of liberty, due process and privacy. It allowed both foreign nationals and US citizens to be detained as enemy non-combatants and restricted their rights to due process. Certain provisions of the Act (16 in total) were subject to sunset clauses that were to expire on the 31 December 2005. Out of the 16 provisions due to lapse

96 A v United Kingdom, App. No 3455/05, judgment of the Grand Chamber, 19 February 2009.

97 Ibid. para. 108.

98 Davis, History and Development, n. 73 above, pp. 64-70.

99 This danger was recognised by Mary Robinson in 1974 when she argued that a specific time limit or renewal clause be inserted in the Offences Against the State Act 1939. See M Robinson, The Special Criminal Court (Dublin: Dublin UP 1974), p. 36. However, as we shall see, this would probably have had no practical effect on preventing entrenchment.

100 S. 2 invests the power of making a non-derogating control order in the Home Secretary.

101 Justice, "Draft Prevention of Terrorism Act 2005 (Continuance in Force of Sections 1 to 9) Order 2010 Justice Briefing for House of Commons Debate", March 2010, para. 8.

102 Ibid at para. 12-15.

103 Prevention of Terrorism Act 2005 (Continuance in Force of Sections 1 to 9) Order 2010. 
on the that date, 14 were not only renewed but made permanent, and the provisions relating to wire-tapping were given a new four-year extension.

One only has to look at the rhetoric surrounding the CJAA 2009 to understand that in practical terms s. 8(4) will not prevent the permanent encroachment of emergency powers in the legal system. Minister Ahern stressed that the fight against organised crime would be long and tough. The Act was subsequently renewed by the Oireachtas on 24 June 2010 despite the fact that the Director of Public Prosecutions had not directed any cases to be tried in the Special Criminal Court. ${ }^{104}$ Again, Minister Ahern stressed that combating organised crime would be a long process:

In passing the 2009 Act, I do not think anyone expected instant results. Given the nature of organised crime, the investigation and prosecution can be lengthy and difficult, particularly given the power that criminal gangs hold over those who are involved with them. The 2009 Act has been in operation for just under a year at this stage and while there have been arrests under the relevant sections of the Act, no cases have yet come before the Special Criminal Court. This does not, however, invalidate the reason for having such a provision available for use in appropriate circumstances. 105

Rather than undermining its necessity, the lack of use of s. 8 was considered by Senator Denis O'Donovan to justify its renewal as it reinforced its position as "extraordinary"106 and only to be used as "a last resort"107 thus mitigating its draconian nature. Senator O'Donovan also considered the yearly renewal clause to be "frustrating . . . [as] . . . each year this matter must be brought before the Oireachtas". 108 He considered a renewal period of "every two or three years" to be appropriate. 109

Similarly, overuse of the Act is unlikely to ring alarm bells as to its encroachments on civil liberties. Detention powers under the Criminal Justice (Drug Trafficking) Act 1996, which are widely used, were subject to a similar renewal clause and were consequently renewed on a number of occasions, most recently until 31 December 2010. Section 21 of the CJAA 2009 removes this renewal clause, however, because Minister Ahern stressed that:

at the time of the enactment... detention of up to 7 days was considered a major departure. However, those detention powers are now an established and essential part of the fight against drug crime. ${ }^{110}$

Rather than protecting against encroachment, the renewal clause became seen as a blockade to the effective running of normal police investigative procedures. The result is that, as with the changes introduced in the Criminal Justice (Drug Trafficking) Act 1996, extraordinary measures will become normalised over time, changing the legal system permanently. Time limits are of little assistance in preventing this. Senator O'Donovan's contribution to the renewal debate surrounding s. 8 indicates that a similar frustration with the s. 8(4) time limit may occur also. These encroachments on human rights, like the emergency itself, become permanent.

104 Joint Committee on Justice, Defence and Women's Rights, 24 June 2010, p. 2, http://debates.oireachtas.ie/ DDebate.aspx?F=JUJ20100624.XML\&Ex=All\&Page=2. See also F Gartland "No gang case taken in Special Criminal Court", Irish Times, Dublin, 25 June 2010.

105 Joint Committee on Justice, Defence, n. 104 above.

106 Ibid.

107 Ibid.

108 Ibid.

109 Ibid.

110 Dáil Debates, vol. 687, No 2, 3 July 2009. 


\section{THE PERMANENT EMERGENCY AND THE LIBERAL-DEMOCRATIC ORDER}

One can thus project that, in the aftermath of the CJAA 2009, Ireland is now in a state of de facto permanent emergency as regards organised crime. By its nature, an emergency should be exceptional. This is reflected by its synonym: a state of exception. ${ }^{111}$ It must therefore constitute a rare response to a rare phenomenon and must also be a prohibited course of action when normal conditions exist. As empirical evidence in modernity has shown, the state of exception has now become so frequent that many academics argue it is essentially permanent. ${ }^{112}$ The de facto emergency that now pertains in relation to organised crime in Ireland further corroborates this assertion. It is upon this observation of the unexceptional emergency that Carl Schmitt bases his attack on the liberal-democratic order. ${ }^{113}$ States of emergencies are not merely limited to liberal-democratic constitutions, however, their inclusion in these constitutions fundamentally undermines the very values that a liberal-democratic state cherishes: liberalism and democracy. By recognising conditions whereby the values of liberalism and democracy cannot be realised lest ruin be visited upon the state, Schmitt argues that a liberal-democratic order is incapable of protecting a state's citizens, which is the fundamental goal of the state. ${ }^{114}$ Consequently, in periods of emergency, these states must reach for a blunter, embryonic form of governance: absolute power in a dictatorial head of state, namely the sovereign. ${ }^{115}$ It is thus a dictatorial form of governance that is ultimately capable of securing the very existence of the state. In order to do this, however, the sovereign needs to be free from the rule of law and able to exercise his or her decision-making powers effectively. ${ }^{116}$ Only then is the sovereign capable of effectively exercising the ultimate political act: distinguishing between "friend" and "enemy" and consequently protecting the state by creating a state of exception. ${ }^{117}$ This distinction between friend and enemy is, Schmitt argues, incapable of being described or controlled by a legal norm. So, too, therefore, is a state of emergency incapable of such a legal-normative description. This theory thus formulates itself in its simplest and most famous form as: "Sovereign is he who decides the exception." 118 The weakness of the liberal-democratic order is further corroborated by the frequency with which states resort to emergency powers. This permanent emergency, according to Schmitt, is merely the logical conclusion of the liberal-democratic order, with the sovereign showing his or her true face in times of crisis. ${ }^{119}$

When one applies Schmitt's theory to the CJAA 2009, Ireland's status as a liberaldemocratic state with respect for human rights is compromised by an emergency response that will have a permanent effect on the political and legal landscape. ${ }^{120}$ The ordinary legislative process is portrayed as incapable of accommodating the phenomenon of organised crime as it is unable to react in a sufficiently swift and decisive manner.

111 See, generally, G Agamben, State of Exception (London: University of Chicago Press 2005), p. 4.

112 Ibid. See also Gross, "Chaos and rules”, n. 15 above, pp. 1089-94.

113 See, generally, C Schmitt, Political Theology: Four chapters on the concept of sovereignty (Cambridge MA: M1T Press 1988). See also O Gross, “The normless and exceptionless exception: Carl Schmitt's theory of emergency powers and the 'norm-exception' dichotomy" (1999-2000) 21 Cardozo Law Review 1825, pp. 1847-8.

114 C Schmitt, The Crisis of Parliamentary Democracy, E Kennedy (trans.) (London: MIT Press 1985), p. 28.

115 Ibid. pp. 28-32. See also Schmitt, Political Theology, n. 113 above, ch. 1.

116 Schmitt, Political Theology, n. 113 above, ch. 1.

117 See C Schmitt, The Concept of the Political, G Schwab (trans.) (London: University of Chicago Press 2007), p. 26.

118 Schmitt, Political Theology, n. 113 above, p. 5

119 See, generally, Schmitt, The Crisis, n. 114 above. See also Gross, “The normless”, n. 113 above, pp. $1847-8$.

120 See S Kilcommins and B Vaughan, "A perpetual state of emergency: subverting the rule of law in Ireland" (2004) 35 Cambrian Law Review 55, pp. 72-4. 
Consequently, the government, by "necessity" consolidates its power at the expense of the legislature to rush the legislation through. ${ }^{121}$ Evidently, during periods of normalcy in Ireland, the separation of powers between the executive and legislature is already extremely weak given the requirement that members of the government must also be members of the Oireachtas and are elected by the Oireachtas. ${ }^{122}$ However, it is submitted that the use of the guillotine procedure in passing the CJAA 2009 effectively enshrines the singular wishes of the executive into law with minimal interference from, or dilution by, the legislature. Guillotining of debate time on the CJAA 2009 to 90 minutes effectively erased the already weak separation between the legislature and executive that exists under the Irish Constitution. ${ }^{123}$

Such a system is more symptomatic of a dictatorial regime than a liberal-democratic order with a separation of powers doctrine. Kilcommins and Vaughan argue that a wholly Schmittian "emergency" is unlikely in Ireland given that a state of emergency in accordance with Article 28.3.3 of the Irish Constitution, which suspends the rule of law completely, will probably not be declared. Rather, limited zones of non-legal applicability are created which are often expanded. They, as I do here, argue that these zones have expanded to cover organised crime. However, where I distinguish my position from Kilcommins and Vaughan is in their belief that, as a state of emergency has not been declared, this will stop a Schmittian dystopia. Rather, as the shielding effect of emergencies has been eroded to a point of futility, and a de facto emergency is in existence, an official de jure declaration of a state of emergency is not needed to prevent a dystopian Schmittian outcome. All that is needed is for the political sphere to supersede the rule of law.

Liberalism, a respect for human rights and the rule of law are all undermined by the CJAA 2009. The right to trial by jury as recognised in the Irish Constitution and international human rights law is cast as an obstruction, hampering the state's ability to protect its citizens from the perceived threat at hand. This barrier is thus removed, no longer curtailing the state's actions and, consequently, its duty to protect the citizen. Schmitt is again affirmed as the dictatorial nature of the state reveals itself as unshackled by the law. The state is thus left free to utilise actions to engage with the identified "enemy". The dystopian outcome of a Schmittian analysis of Ireland is even more pronounced given the relatively low threat that organised crime evidently poses to the life of the nation. ${ }^{124} \mathrm{We}$ are thus presented with a state that reacts to a low-level threat by curtailing the very fabric of the constitution that distinguishes it as a democratic document which affirms human rights.

\section{SHIELDING THE EMERGENCY}

The use of an emergency response to deal with low-level threats corroborates with the thesis of Mark Neocleus ${ }^{125}$ who offers an alternative explanation to why it is increasingly difficult to differentiate between normalcy and emergency. Ideally, one could avoid this abuse of the term emergency by looking beyond whether the phenomenon is described as an emergency and instead focus on whether the response equates to an emergency response, in other words through application of the methodology used here. However, as

121 See F de Londras and C Kelly, European Convention on Human Rights Act: Operation, impact and analysis (Dublin: Roundhall 2010), pp. 235-6.

122 Article 28.7.1 of the Irish Constitution states that the Taoiseach and Tánaiste must be members of Dáil Eireann. Article 28.7.2 states that the other members of government must be members of either the Dáil or Seanad but with not greater than two members from the Seanad.

123 de Londras and Kelly, European Convention, n. 121 above, pp. 235-6.

124 Kilcommins and Vaughan, "A perpetual state", n. 120, pp. 76-7.

125 M Neocleous, "The problem with normality: taking exception to permanent emergency" (2006) 31 Alternatives 191. 
has been shown, an emergency response does indeed accurately describe the CJAA 2009. Neocleus' second argument is thus affirmed: that the range of phenomena which are subject to emergency responses has also increased. ${ }^{126}$ Emergency powers are no longer used merely to deal with armed invasions and natural disasters but with terrorist threats and, indeed, economic disasters. The increasingly diminishing severity threshold which crises must meet in order to constitute an emergency makes it ever more difficult to discern normalcy from emergency. This also has the effect of destroying the potential shielding effects of a state of emergency. Firstly, as an emergency under Article 28.3.3 of the constitution was never declared, we are left with a situation in which draconian measures are enacted while a de jure state of normalcy prevails. Human rights, democracy and the rule of law are thus constrained to a level symptomatic of an emergency. However, as this is "normalcy", this level now becomes the status quo. Thus, these restrictions become normal and perpetual, rather than exceptional and temporary. Secondly, and more importantly, even if a state of emergency were declared, the emergency-normalcy response is rendered folly as the term emergency is one devoid of any tangible meaning. Its elastic nature is stretched to the point where it breaks and the theoretical underpinnings of the emergency-normalcy dichotomy become increasingly refuted despite their potential merit. Thus, this severity threshold is lowered to such a level that the shielding effect of emergencies is destroyed.

\section{Conclusion}

States of emergency, whether de facto or de jure, have serious consequences for democracy, human rights and the rule of law. Utilised effectively, a temporary aberration from these obligations can ultimately preserve the state and the liberal-democratic order. In addition, insistence on a de jure state of emergency can protect these rights further. Of course, organised crime has serious consequences for both individuals and communities, yet it is submitted that the severity of the threat is not such as to cross the threshold into a state of emergency. That notwithstanding, the state has responded to the phenomenon of organised crime as if it were of sufficient magnitude to threaten the life of the nation. In addition, the ordinary democratic procedure was treated by the government as a barrier to tackling this phenomenon. The emergency response paradigm was thus lowered to cover a phenomenon that does not threaten the existence of the state and became stretched to a point where it absorbed a phenomenon that exists in normalcy. Consequently, there appears a negligible difference between normalcy and emergency, and emergency responses become viewed as increasingly normalised. The non-jury Special Criminal Court, which was once established to deal with dissidents who did actually challenge the authority of the state, ${ }^{127}$ is now used to deal with criminal activities devoid of a political element. The permanent feature of the Special Criminal Court in the Irish legal system stands as a testament to the dangers of utilising an emergency response to deal with a phenomenon such as terrorism which blurs the lines of demarcation between normalcy and emergency. The expansion of the Special Criminal Court to deal with organised crime further blurs this distinction.

If a war on terror is often considered unwinnable, what hope is there for a state in winning the war on organised crime? What is the acceptable level of organised crime in a state in order for these measures to be relinquished or must all organised crime be eliminated? Calls for internment ${ }^{128}$ for participants in organised crime are perhaps the ultimate example of the negative consequences that can ensue when the nuclear option of

126 Neocleous, "The problem”, n. 125 above, p. 195.

127 Davis, History and Development, n. 73 above, pp. 64-70.

128 V Robinson, "Latest murder sparks calls for internment of Limerick gangs”, Irish News, Belfast, 3 March 2010. 
an emergency response is employed to deal with such a low-level threat to the state. When an even more serious threat to the state is evident, one can assume that it will respond with even more draconian measures. If citizens were prepared to accept internment to deal with organised crime, one can only postulate at the dystopian state that may ensue if a more pertinent and real threat to the life of the nation were to come into existence.

Emergencies are supposed to constitute a threat to the life of the nation. In utilising emergency responses when dealing with increasingly low-level threats such as organised crime, the state erodes this definition further. Ireland is a liberal democracy that affords a prominent level of respect to human rights in its constitution. It is these values that represent the true life of the nation and draconian laws eroding these fundamental principles that constitute the real threat to it. ${ }^{129}$

129 See Lord Hoffman's dissent as to the existence of a state of emergency in the UK in $A$ v UK [2009] All ER 203, para. 108. 
